IRA-International Journal of Management \& Social Sciences

ISSN 2455-2267; Vol.06, Issue 01 (2017)

Pg. no. 24-30

Institute of Research Advances

http://research-advances.org/index.php/RAJMSS

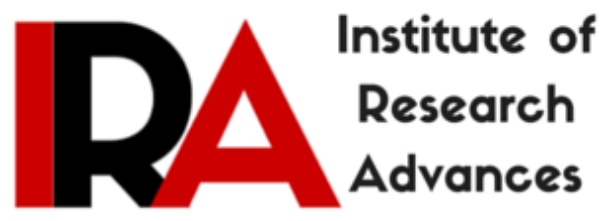

\title{
Women Workers in Agricultural Sector: A Literature Review
}

\author{
Neela Multani ${ }^{1}$, \\ Research Scholar, C. U. Shah University, \\ Wadhwan, Surendranagar, Gujarat, India. \\ Dr. A. N. Sanghvi ${ }^{2}$ \\ Research Supervisor, C.U. Shah University, \\ Wadhwan, Surendranagar, Gujarat, India.
}

Type of Review: Peer Reviewed.

DOI: http://dx.doi.org/10.21013/jmss.v6.n1.p4

\section{How to cite this paper:}

Multani, N., \& Sanghvi, A. (2017). Women Workers in Agricultural Sector: A Literature Review. IRA-International Journal of Management \& Social Sciences (ISSN 2455-2267), 6(1), 24-30. doi:http://dx.doi.org/10.21013/jmss.v6.n1.p4

(C) Institute of Research Advances

$(\mathrm{cc})$ BY-NC

This work is licensed under a Creative Commons Attribution-Non Commercial 4.0 International License subject to proper citation to the publication source of the work.

Disclaimer: The scholarly papers as reviewed and published by the Institute of Research Advances (IRA) are the views and opinions of their respective authors and are not the views or opinions of the IRA. The IRA disclaims of any harm or loss caused due to the published content to any party. 


\begin{abstract}
For any research, literature review is an essential part as it helps in identifying the area of research. Agriculture is the main source of sustenance for both developing and under developed countries. In countries like India, women's position is not as strong as men both economically and socially and she faces more constraints than men. They cannot relocate easily. Women in rural areas have to manage multiple activities like maintaining home, making food, arranging water etc. and they are working in farms also. So, they are living hard life. All the activities performed by rural women is essential for the well-being of the rural households, still they are not defined as 'economically active employment' in national accounts. In India, 24 percent to total workers work as female cultivators and 41.1 percent to total workers work as female agricultural labourers. Past studies also relieved that because of less education, unawareness about the laws, poverty and gender discrimination, women workers face many problems. Also, few studies show that in some parts of the nation women workers are being paid less than the male workers. This Paper reviews past research studies to highlight the role and position of women workers in agricultural sector.
\end{abstract}

Keywords: Agricultural sector, Literature Review, Women workers

\title{
1. INTRODUCTION
}

India is a developing country having the second largest arable land in the world. About $60 \%$ population of India is depending on agriculture. Because of this only India can survive even during recession period. Therefore, agriculture is a backbone of India. Agriculture contributes in India's national income as well as it helps in generating employment in the country. Only because of the agriculture, India can meet the food demand of ever-increasing population.

Agriculture is the main source of sustenance for both developing and under developed countries. Human civilization history shows that the emergence of agriculture was the beginning of settled life. Settlement of nomadic people emerges relationships of family and women assumed a special role in the family and they started to live near rivers for production of food. So, we can say that beginning of agriculture had a special significance in defining and determining the role and status of women throughout the world [1].

In our male dominated society, most of the power lies with men, and women are cultural victims. Men enjoy superiority and women face hardship. If women had been given equal opportunities as men, the growth and prosperity of the country would have been manifold. There are different traditional attitudes towards men and women which confined women to the role of homemaker. Though now like other countries of the world, Indian rural women are actively participating in various agricultural activities besides their usual role of homemaker [1].

In countries like India, women's position is not as strong as men both economically and socially. Also she faces more constraints than men. They cannot relocate easily. Women in rural areas have to manage multiple activities like maintaining home, making food, arranging water etc. and they are working in farms also. So, they are living hard life. All the activities performed by rural women is essential for the well-being of the rural households, still they are not defined as 'economically active employment' in national accounts [2].

\section{CONTRIBUTION OF AGRICULTURE IN WORLD'S, INDIA'S AND GUJARAT'S ECONOMY}

Agriculture is known as a fundamental instrument for sustainable development and it helps in poverty reduction as it is the main source of food, income and employment for the rural population of the world. Therefore, we can say that agriculture plays a crucial role in the economy of developing countries. As per the Food and Agriculture Organization (2000), the share of the agricultural 
population in the total populace is $67 \%$. Agriculture accounts for $39.4 \%$ of the GDP and $43 \%$ of all exports consist of agricultural goods [3].

India is mainly agricultural country and agriculture plays a vital role in India's economy. As per the Ministry of External Affairs, Government of India, over 58\% of the rural households depend on agriculture as their principal means of livelihood. Agriculture, along with fisheries and forestry, is one of the largest contributors to the GDP. India is the largest producer, consumer and exporter of spices and spice products. For most of the Indian families, agriculture is the most important occupation. As per the data of year 2015, agriculture contributes about $16 \%$ to the total GDP and about $14.7 \%$ of the total export earnings [3].

Gujarat is a diversified agricultural economy. Agriculture and allied sector plays an important role in the economy of the state. Though its contribution in Net State Development Product (NSDP) has gradually declined from around 50 percent during 1970s to around 21.6 percent in 2010-11, agriculture still considered as a backbone of the state economy because more than half of the working population in the state is still dependent on agricultural activities for their livelihood [3].

\section{WOMEN IN AGRICULTURE}

The dignity of women is largely depends on the availability of employment for women. The casual essence of employment, absence of opportunities to progress, lack of required skills, segregation of work, unequal wages, corrupt surroundings of work, commercialization and mechanization of agriculture are some of the problems that have oppressed the female agricultural labourers. Concentration of vast number of women in this field also reduced the bargaining capacity of laborers. It also affects the wage pattern of these laborers. Women's presence in the labor market is purposeful by her family situation, education, growth in job opportunities and the normal leveled of fiscal action. Female work presence in agriculture depends on a severity and related growth of agriculture [4].

Nearly 80 per cent of the fiscally active women in sub Saharan Africa and at least half in Asia except West Asia are in agriculture [5]. The Indian censuses categories those employed in agriculture into two broad divisions-cultivators and agricultural labourers [6].

\begin{tabular}{|l|c|}
\hline Total Population of India & 1210.85 million \\
\hline Rural Population & 833.7 million \\
\hline Urban Population & 377.1 million \\
\hline Work Participation Rate & $39.8 \%$ \\
\hline Percentage of female cultivators to total workers & $24 \%$ \\
\hline Percentage of female agricultural labourers to total workers & $41.1 \%$ \\
\hline
\end{tabular}

Table 1: Participation rate of women in agricultural sector (Source: Census of India 2011)

As per the census 2011, Gujarat's population is 6.04 crore with 3.15 crore males and 2.89 crore females. The total number of workers in Gujarat is 247.68 lakh and the work participation rate is 41 percent, which is higher than the national average of 39.8 percent. About 70.5 percent of total workers are rural based. Out of 247.7 lakh total workers, 203.7 lakh are main workers and the remaining 44 lakh are marginal workers, which consists of 39.3 lakh (89.3 percent) worked for 3 to 6 months and 4.7 lakh (10.7 percent) worked for less than 3 months in the state. During the year 2001, there were about 58.03 lakh of cultivators in the state, constituting about 27.3 percent of total workers. Among the total cultivators, about 32.7 percent (19 lakh) were women and 51.4 percent of total agricultural labourers were women [7].

\section{EMPLOYMENT OF WOMEN IN INDIAN AGRICULTURAL SECTOR}

Census data shows that there is a dominance of women as agricultural labours than cultivators. Women hold an important post of distinct characteristics in the family and society. No society can establish fully without an important circulation of women approaching its establishment. To subsidize 
to fiscal establishment, women must employ themselves in fiscal or beneficial action. For a full integration of women in fiscal establishment, women must enter the labour force on equal footing with men.

V. Vetrivel, R. Manigandan (2013) in "An empirical study of agricultural labour in India" states that almost half of the world's agricultural workforce comprises of women. They are contributing from production to sale as well as preparation of food. Though traditionally role of women worker in agricultural was under-estimated. Women are working as paid labour or unpaid family member in agriculture in developing countries but they are still facing gender inequalities [8].

Manas Mandal (2013) analysed women participation in agricultural production of Sagar Island, West Bengal, India. He investigated that women perform range of duties at farm and home, also they work for longer hours than men and yet they get less wages and exploited by landlords. They are treated as sub-servant and discrimination is there for female labours [9].

Chandrama Goswami (2013), in "Female agricultural workers in Assam: A case study of Darrang district" concluded that poor women are contributing more to household income by working as a labour even under poor working conditions and with lower wages to improve the economical conditions of the family. There were no land ownership amongst female and even they do not have any right on their earnings. Women accept to work in farms because they can get employment without proper training or education and it is temporary in nature. It was also proved that in spite of having more shares of females as agricultural labour than men, they get lower wages than males [10].

Ghosh (2014) analysed women participation in Agriculture and estimated that $45.3 \%$ of agricultural labour force consists of women but most of them have remained as invisible workers. Study concluded that participation of women in agriculture increasing with time and their status as agricultural labour is now acknowledged. However, wage and working status discrimination is still there [11].

Kanagarathinam (2014) investigated that around 52\% of unorganized workers are engaged in agriculture and allied sectors. Agricultural workers are disadvantages rural groups such as small, subsistence farmers, tenants \& sharecroppers, the unemployed and the landless. They get very low and irregular wages, wage discrimination between male $\&$ females, no public holiday and no standard daily working hours. In addition, they have very poor working conditions, lack of dignity, seasonal unemployment and harassment issues [12].

Swamikannan and Jeyalakshmi (2015) study about women labour in Indian agricultural sector and found that female work participation rate has declined drastically during last few decades, which shows that female workers are moved from agricultural to non-agricultural activities because wage differences between male and female workers for the same type of work discourages female workers [13].

So, all the above studies show that females are largely employed in agricultural sector and their share in agriculture is crucial. In spite of this, they are being ignored by the society.

\section{GENDER DISCRIMINATION ISSUE FACED BY AGRICULTURAL WOMEN}

Research work of various researchers recognized that discrimination prevails between male and female labor force in terms of treatment from employers, working conditions, wages etc. This leads to poor position of women in agricultural sector because they are unrecognized group of workers.

C. U. Thresia (2004) in his paper "women workers in agriculture: gender discrimination, working conditions and health status" pointed out some very important issues of women agricultural workers. The biggest issue was related to physical (abortion, stillbirths, and premature deliveries) and mental health because of the dual work burden, economic and social insecurity, poverty. In addition, they have gender discrimination in terms of proper education, employment and resources, which make them helpless and powerless with low self-esteem. Basic facilities like clean drinking water and 
washroom facilities were also not available in spite of having long working hours with lower wage rates on farms [14].

Lal and Khurana (2011), in their research paper entitled "Gender Issues: The role of women in agriculture sector" discussed about multidimensional roles and obstacles faced by women in terms of employment, wages, dual responsibility, education level. Though women share is very high in agricultural and they are spending more hours for work on farm than men still they are paid less than males for the same work. Women are undervalued because of the predetermined notion that women's basic role is of homemaker. Therefore, they finally concluded that because of the lack of knowledge about their rights, rural agricultural women labors are exploited by their landlords [15].

Lipishree Das (2015) studies about work participation of women in agriculture in Odisha and concluded that women are concentrated in the agricultural sector of labour market. There is discrimination against female labours because women's labour power is considered as unskilled and inferior. Their work is low paid, casual and lacks potential upward mobility [16].

All these studies identified the discrimination against women in agricultural sector. Government has to formulate as well as implement some policies to improve the conditions of women workers.

\section{CHALLENGES FOR AGRICULTURAL WOMEN}

Various studies reveal that agricultural women are facing many challenges on field and at home because of their dual responsibility as homemaker and agricultural worker.

Tahir Munir Butt et. al (2010) highlight the role of women in agriculture development and their constraints in Depalpur, Okara, Pakistan and concluded that male dominance, traditional belief systems, extension education services, lack of mobility \& technical training, knowledge \& skills are the major constraints for female agricultural workers [17].

Dr. Vandana Dave (2012) conducted the study on women workers engaged in unorganized sector to know about the socio-economic background, working conditions, wage rates, living conditions of women workers engaged in unorganized sectors like construction, domestic and agriculture in three districts of Haryana. She concluded that women laborers face problems like excessive work burden, wage discrimination, exploitation, untimely wage payment, seasonal unemployment, job insecurity, health problems. As far as working conditions and facilities are concerned, there were no any facilities like medical/first aid, medical leave, and holidays. Only compensation of injury was given in rare cases in a less amount [18].

Budech (2014) studied about struggles of female farm workers of California. He investigates the gender aspects of fieldwork and few specific struggles faced by female farm workers such as domestic abuse, sexual harassment in the fields, and exposure to pesticides [19].

Mugadur \& Hiremath (2014) studies about socio-economic condition of agriculture women labour in Mangudi village and found that women face many problems like illiteracy, low and irregular wages, scolding \& beating by men etc. They concluded that women do not know how to face these problems [20].

Thus, we can conclude that biggest challenges for females in agricultural sector are illiteracy, lack of training, health issues due to exposure to pesticides [21], domestic abuse, family constraints etc.

\section{CONCLUSION}

Our Prime Minister Shri Jawahrlal Nehru once said that, "You can tell the condition of a nation by looking at the status of women" [22]. So, we can say that growth and prosperity of any country can be measured by the status and development of its women. Almost half of the human resource of the world constitutes women and that is why they influence the growth of nation's economy. According to Swaminathan, the famous agricultural scientist, "some historians believe that it was woman who 
first domesticated crop plants and thereby initiated the art and science of farming. While men went out hunting in search of food, women started gathering seeds from the native flora and began cultivating those of interest from the point of view of food, feed, fodder, fibre and fuel [23]. In spite of working for longer hours in farms than males, females are facing gender discrimination. There is a quantitative increase in women's economic participation but it is not matched with the qualitative improvements in their working conditions. Even after the almost seven decades of independence, Indian women continue to be a neglected mass and still over exploited because of illiteracy and social status [24]. Women workers have no facilities like regulated working hours, good working conditions, maternity benefits, and medical assistance etc. which are available to organised sector's female workers. So, work status of female agricultural workers in India is still more or less similar to what it was decades ago. Most of the studies conducted in various countries conclude that women contribution in agriculture is much more than its acknowledgement.

\section{References}

[1] Shubham Mishra (2009). Thesis on role and status of women in agricultural development in Kanpur district, Faculty of home science, Bundelkhand Universtiy, Jhansi.

[2] Chowdhry, Prem (1993). "High Participation and Low Evaluation: Women and Work in Rural Haryana" in Economic and Political Weekly, Vol. 28 No. 52: A 135-47

[3] Government of Gujarat (2015). "Socio-economic Review 2014-15." Directorate of Economics and Statistics, Gujarat State, 2015

[4] Lilly P. V. (2000). Thesis on role of women in agriculture: a case study of female agricultural labourers in Palakkad district of Kerala, Department of Economics, University of Calicut.

[5] The SOFA Team and Cheryl Doss (2011). "The Role of Women in Agriculture. ESA working paper No. 11-02, March 2011

[6] Government of India. A. S. Union Primary Census Abstract 2011

[7] Government of Gujarat (2011). Agriculture Census 2010-2011. Gujarat state

[8] Vetrival V., Manigandan R. (2013). "Am empirical study of agricultural labour in India.” Journal of exclusive management science, Vol. 2, Issue 12.

[9] Mandal M. (2013). "The Role of Rural Women in Agriculture Sector of Sagar Island, West Bengal, India.” The International Journal of Engineering \& Science, vol. 2, Issue 2, pp 81-86.

[10] Goswami Chandrama (2013). "Female agricultural workers in Assam: A case study of Darrang District." International Journal of Scientific and Research Publications, vol. 3, Issue 2, pp 1-5.

[11] Ghosh M. \& Ghosh A. (2014). "Analysis of women participation in Indian Agriculture." IOSR Journal of humanities and social science, Vol. 19, Issue 5, Ver, IV, pp 01-06.

[12] Kanagarathinam M. (2014). "Problems of unorganized (agricultural) workers in Coimbatore." International journal of HRM \& Research, vol. 4, Issue. 6, pp 87-90, Dec 2014.

[13] Swamikannan D. \& Jeyalakshmi C. (2015). "Women labour in Agriculture in India: some Facets." International Journal of business and economics research, vol. 1, No. 1, Nov. 2015, pp 22-28.

[14] Thresia C. U. (2004). "Women workers in agriculture: gender discrimination, working conditions and health status". Discussion paper No. 85, Kerala Research Program on local level development, Center for development studies. ISBN: 81-87621-88-5.

[15] Lal R. \& Khurana A. (2011). "Gender issues: the role of women in agricultural sector." ZENITH International Journal of Business Economics \& Management Research, Vol.1, Issue 1, pp. 29-39. 
[16] Das L. (2015). "Work participation of women in agriculture in Odisha." IOSR Journal of humanities and social science, vol. 20, Issue 7, ver. III (July 2015), pp 66-78.

[17] Butt T. M. et. al (2010). "Role of rural women in agricultural development and their constraints." Journal of agriculture \& social sciences. 09-068/ZIP/2010/6-3-53-56

[18] Dave V. (2012). "Women workers engaged in unorganised sector." Women's Link, Vol. 18, No. 3, pp 9-17.

[19] Budech, Keiko A. (2014). "Missing voices, hidden fields: The gendered struggles of female farm workers. Prizer senior thesis. Paper 54

[20] Mugadur N. S. \& Hiremath R. C. (2014). "Socio-economic condition of agriculture women labour: A case study.” Indian Journal of Research, vol. 3, Issue 12, Dec. 2014.

[21] Devi I. P. et al (2012). "Compensating wages for occupational health risks of farm workers in India.” Working paper 71/2012.

[22] Yatendra Kumar Tyagi (2006). Thesis on a study of women's contribution in agriculture and home development in Meerut region, Ch. Charan Singh University, Meerut.

[23] Duvvury, N. 1989. "Women in Agriculture: A review of Indian Literature" in Economic and Political Weekly, Vol. 24, No. 43: WS 96-112

[24] Abha Singh Kushwala (2009). Thesis on role of farm women workers in agricultural economy in district Meerut (U.P.) with special reference to employment, wage structure and level of income, Bundelkhand University, Jhansi. 